\title{
A NOVEL APPROACH TO QUANTIFYING THE DEGREE OF ANTHROPOGENIC SURFACE TRANSFORMATION - THE CONCEPT OF 'HEMEROMORPHY'
}

\author{
Péter Rózsa, József Incze, Szabolcs Balogh and Tibor József Novák
}

With 3 figures and 2 tables

Received 31 August 2019 · Accepted 7 March 2020

\begin{abstract}
Summary: The degree of human geomorphological impact was estimated as a ratio of natural geomorphological processes and geomorphological processes triggered or facilitated by humankind. A typical Central European cultural landscape of diverse land use and relief was considered as a pilot area. Based on topography maps and landforms the natural material fluxes were calculated. By overlapping historical maps, modern maps and remotely sensed data, the duration and extent of different land use types were mapped, and were assigned to each landscape unit. Anthropogenic material fluxes were calculated for the land use types identified. Dividing the summarized anthropogenic material fluxes by natural ones, the anthropic geomorphological transformation ratio $\left(r_{A G}\right)$ was estimated. The value of $r_{A G}$ is independent of the efficiency and intensity of processes; it merely expresses the relation of effectiveness between human induced and natural processes. Since the calculated index is based on estimated values and there is, at least theoretically, no upper limit, the term 'hemeromorphy' was introduced and the values were classified in corresponding 'hemeromorphphy' categories. For the smallest landscape units with the same degree of 'hemeromorphy' the term 'hemeromorphotop' was applied. This interpretation makes the comparison of landscape units possible according to their anthropogeomorphological transformation, independently of the intensity and quality of their geomorphological processes.
\end{abstract}

Zusammenfassung: Der Grad der geomorphologischen Einflüsse des Menschen wird als Verhältnis zwischen natürlichen geomorphologischen Prozessen und durch den Menschen ausgelöste oder begünstigte geomorphologischen Prozessen betrachtet. Eine typische mitteleuropäische Kulturlandschaft mit vielfältiger Landnutzung und Relief wird als Modellgebiet betrachtet. Auf der Grundlage topographischer Karten und Landformen werden zunächst die natürlichen Stoffflüsse berechnet. Durch die Überlagerung von historischen Karten, aktuellen Karten und Fernerkundungsdaten werden Dauer und Ausmaß der verschiedenen Landnutzungstypen kartiert und den einzelnen Landschaftseinheiten zugeordnet. Für die identifizierten Landnutzungstypen werden die anthropogenen Materialflüsse berechnet. Durch die Division der zusammengefassten anthropogenen Materialflüsse durch die natürlichen Materialflüsse wird das anthropogene geomorphologische Transformationsverhältnis $\left(r_{A G}\right)$ geschätzt. Der Wert $\operatorname{der} r_{A G}$ ist unabhängig von der Effizienz und Intensität der Prozesse; er drückt lediglich das Verhältnis der Effektivität zwischen menschlich induzierten und natürlichen Prozessen aus. Da dem berechneten Index geschätzte Werte zugrunde liegen und es, zumindest theoretisch, keine obere Grenze gibt, wird der Begriff 'Hemeromorphie' eingeführt und die Werte in entsprechende 'Hemeromorphie' Klassen eingeteilt. Für die kleinsten Landschaftseinheiten gleichen 'Hemeromorphie' Grads wird der Begriff 'Hemeromorphotop' verwendet. Die Interpretation ermöglicht den Vergleich von Landschaftseinheiten entsprechend ihrer anthropo-geomorphologischen Transformation, unabhängig von der Intensität und Qualität der geomorphologischen Prozesse.

Keywords: geomorphology, anthropogenic surface transformation, quantification in anthropogeomorphology, Hungary

\section{Introduction}

Since the introduction of the concept of anthropic geomorphology (SHerlock 1922, 1931; NIR 1983) numerous analytical studies have demonstrated that anthropogenic transformation of the Earth's surface could be as effective in actual surface forming as natural transformations (Goudie 1993; Hooke 1994, 1999, 2000; Giardino and Marston 1999; HafF 2003; RózsA 2007, 2010); therefore, as regards geomorphological processes we undoubtedly live in the 'Anthropocene', a new geological epoch (ZALASIEWICZ et al. 2011). Moreover, at the turn of the millennium at least one third of the Earth's continental surface had undergone direct or indirect human transformation (LOH and WaCKERnAGel 2004), including anthropic geomorphological activity. Human intervention on the surface has become a geological factor, which is indicated by the fact that 'artificial ground', a category used for decades on British geological maps, has recently been categorized into a series of 'domains' (FORD et al. 2010). In densely populated regions the rate of human modified surface development far exceeds that of natural processes; however, it may also be important to distinguish areas affected by higher and lower grades of human geomorphological influence in these cases (GARES et al. 1994; CENDERO et al. 2001; Phillips 2009). 
To evaluate landforms according to the grade of their anthropogenic transformation, numerous approaches have been published, initially aimed at estimating its significance in landscape changes (Lausch and Herzog 2002) or its hazardous character (BorgatTI and Soldati 2005). Some studies have dealt with the quantification of human impacts on landforms in a comprehensive manner (VERSTRAETEN at al. 2009; VANWALLEGHEM et al. 2017), but most of them have focused on the details with elaborated overviews of just one particular group of anthropogenic landforms, e.g. for coastal and estuarine areas (Pye and Blott 2014; Ferrer-Valero et al. 2017), mining regions (HARnischmacher and Zepp 2014; Byizigiro 2015; Dulias 2016), flood managed catchments (SLABÁ et al. 2015), and agricultural land (Martinez-Casasnovas 2003; Houben et al. 2006; CHARTIN et al. 2013); moreover, there has also been an attempt to quantify the impact of transportation (SofiA et al. 2016). During the last decade, review articles (Price et al. 2011; Brown et al. 2017) and summarizing text-books (SZABÓ et al. 2010; GOUDIE and VILES 2016) have also appeared.

Some attempts at mapping the human transformation of the surface, in general, based on a comprehensive perspective have also been made. One of the first attempts was made by Hooke (1999) who presented the spatial distribution of the soil and bedrock material moved per year by human action, comparing it to fluvial erosion in the United States. Lóczy and Pirkhoffer (2009) mapped the direct human impact on topography of Hungary, principally based on land use patterns. Recently, a detection of anthropogenic topographic signature by using satellite data has been attempted (TAROLLI 2014; TAROLLI et al. 2017) based on the empirically identified relationship between the degree of landscape organization, expressed by landscape metrics, and the amount of human-made alteration.

The aim of our study is to introduce a novel concept named 'hemeromorphy' which allows for the determination and mapping of the degree of human transformation. Regarding the analogy of the 'hemeroby' concept (Jalas 1955; Sukopp 1969), which expresses the degree of human influence on vegetation and ecosystems, hemeromorphy expresses the degree of human influence on geomorphosystems (complexes of surface forming processes) independently of their geomorphic process combinations, relief and climate. The concept of 'anthromes' introduced by ElLis and RAmankUTTY (2008) allows for a similar evaluation of ecosystems. To apply the concept, diverse anthropic geomorphologic processes shap- ing the actual surface must be localized and identified; then the results of natural and anthropogenic geomorphologic processes have to be quantified and compared; furthermore, the rate of mass translocation by natural processes and that of human geomorphologic activities is determined, ignoring their spatial complexity and temporal variability. This kind of abstraction allows us to distinguish different areas according to the degree of human transformation, and to compile anthropo-geomorphologic maps. The application of the concept is demonstrated on the example of Tokaj Nagy Hill (NE Hungary), an emblematic site in the World Heritage Tokaj Wine Region Cultural Landscape, a typical Central European hilly cultural landscape with a traditionally diverse land use structure.

\section{Methods (Mapping and estimation of geo- morphological processes)}

The anthropogenic processes that affected the pilot area are ranked on the basis of the magnitude of the volume moved, converted into mass under a definite time unit, which measures their effectiveness in material dislocation. The spatial units can be characterized by the geomorphological (natural or anthropogenic) process with the highest rate of material transport. It can be regarded as the dominant geomorphological process, because it is, has been, or it was, for a certain period the most effective surface forming factor.

To compare natural and anthropogenic processes, first of all the total amount of natural, or quasi-natural background-processes has to be expressed as the material-transportation rate $\left(\mathrm{t} \cdot \mathrm{ha}^{-1} \cdot \mathrm{yr}^{-1}\right)$ and estimated for the whole pilot area. The area is divided into homogeneous spatial units, in which material transportation has the same order of magnitude. Historical maps and later topographic and remotely sensed datasets allows us to divide the study period into distinct sections. Overlaid, cross-sectioned and reorganized land use patterns allow to compile the anthropo-geomorphological map of the pilot area.

In the second step, the volume of material moved by anthropogenic processes was calculated. The relevant processes were grouped in spatial units mapped by the dominant anthropogenic processes. To establish the spatial pattern of dominant anthropogenic processes, land use data of historical maps, topographic maps, aerial photographs and satellite images of different ages were used. In order to unitise all data from the maps, aerial photographs and satellite 
images, the land use was reclassified into uniform and consistent land use classes. From overlaid and cross-sectioned maps an anthropo-geomorphological map can be compiled, in which the most effective anthropogenic process which appeared during the studied time-interval was assigned to every spatial unit.

To express the degree of anthropo-geomorphological influence on the surface, the ratio of anthropo-geomorphological transformation $\left(r_{A G}\right)$ was expressed as follows:

$$
r_{A G}=M_{A} \cdot M_{N}^{-1}
$$

where $M_{A}=$ magnitude of dislocated material by human activities; $M_{N}=$ magnitude of dislocated material by natural processes (both in $\mathrm{t} \cdot \mathrm{ha}^{-1} \cdot \mathrm{yr}^{-1}$ ). This approach enables us to quantify the degree of anthropic geomorphological transformation in spatial units. The smallest landscape units, which are homogeneous according to their hemeromorphy, could be referred

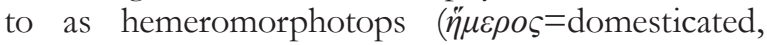
educated, $\mu о \rho \varphi \tilde{\eta}=$ form, $\tau о \pi \circ \varsigma=$ place, locality). Lower $r_{A G}$ values characterize landscapes of very moderate anthropic geomorphological transformation, while high values indicate totally artificial surfaces, where the amount of anthropogenic dislocated material is much higher than that of natural transportation.

To determine the amount of dislocated material by natural and anthropic processes, data derived from field measurements, satellite imagery, and collected from earlier studies, historical maps, etc. should be used as input data. As a result of the data processing (which includes mapping natural and anthropic geomorphological processes and forms, tracing temporal and spatial changes in land use pattern, and quantifying material transports) the magnitude of natural and human transported material as output data can be obtained; moreover, based on the $r_{A G}$ values, map units can be classified (Fig. 1).

In our opinion, $r_{A G}$ values ranging from $r_{A G}<10$, in the case of agricultural, hilly areas, to $r_{A G}>10000$ in the case of quarries, can be divided into hemeromorphy levels, as follows:

- ahemeromorph (no or negligible human impact), where $r_{A G} \approx 0$

- oligohemeromorph (low human impact), where $r_{A G}<1$

- mesohemeromorph (moderate human impact), where $r_{A G}=1-10$

- euhemeromorph (high human impact), where $r_{A G}=10-100$

- polyhemeromorph (very high human impact), where $r_{A G}>100$

- metahemeromorph, (completely human controlled geo-environment), $r_{A G}$ not defined.
Moreover, based on the intentional or unintentional character of anthropogenic activity resulting in material relocation, eu- and polyhemeromorph categories can be divided into $\alpha$ and $\beta$ subcategories, respectively.

To identify the spatial pattern of dominant anthropogenic processes, land use, data from the 1st, 2nd, and 3rd Military Surveys (1785, 1858, 1884) (ArCanum 2004, 2005, 2007), topographic maps (1:25000, 1959; 1:10000, 1989), aerial photographs (1957, 1981, 2000) and satellite images (2000, 2011 Google Earth) were used. Based on cartographic land use data, the duration of surface forming anthropogenic processes was also estimated, as far as it was possible. Maps were converted into the same, Uniform National Projection (EOV) with Quantum GIS 2.12. Remote sensed data were orthorectified with Erdas Imagine 8.5 software. All land use data of maps, aerial photographs and satellite images were uniformized by categories (forests, grasslands, plough lands, vineyards, quarries, erosion gullies and built-up areas were distinguished) and vectorized with ArcGIS software.

The natural geomorphological components $\left(M_{N}\right)$ forming the surface of the Nagy Hill are:

- sheet erosion, soil creeps $\left(M_{n e}\right)$,

- linear erosion, natural gully development $\left(M_{n g}\right)$,

- dust deposition and dust emission $\left(M_{n d}\right)$.

$$
M_{N}=M_{n e}+M_{n g}+M_{n d}
$$

The relevant components of anthropogenic geomorphic processes $\left(M_{A}\right)$ during the study period (the last almost 300 years) have been:

- accelerated erosion due to deforestation, grazing and fire $\left(M_{a c}\right)$,

- tillage erosion of cultivated areas $\left(M_{a t}\right)$,

- landscaping, terracing $\left(M_{a t}\right)$,

- gully development due to long-time cultivation $\left(M_{a g}\right)$,

- material loss by quarrying $\left(M_{a q}\right)$;

- material loss and surplus due to constructing and maintaining dust-free roads, railways and builtup areas $\left(M_{a b}\right)$

Consequently:

$$
M_{A}=M_{a e}+M_{a t e}+M_{a t}+M_{a g}+M_{a q}+M_{a b}
$$

To quantify the processes, two different concepts were applied. Firstly, we calculated with process rates data, measured on the basis of maps, remotely sensed data, and completed with field 


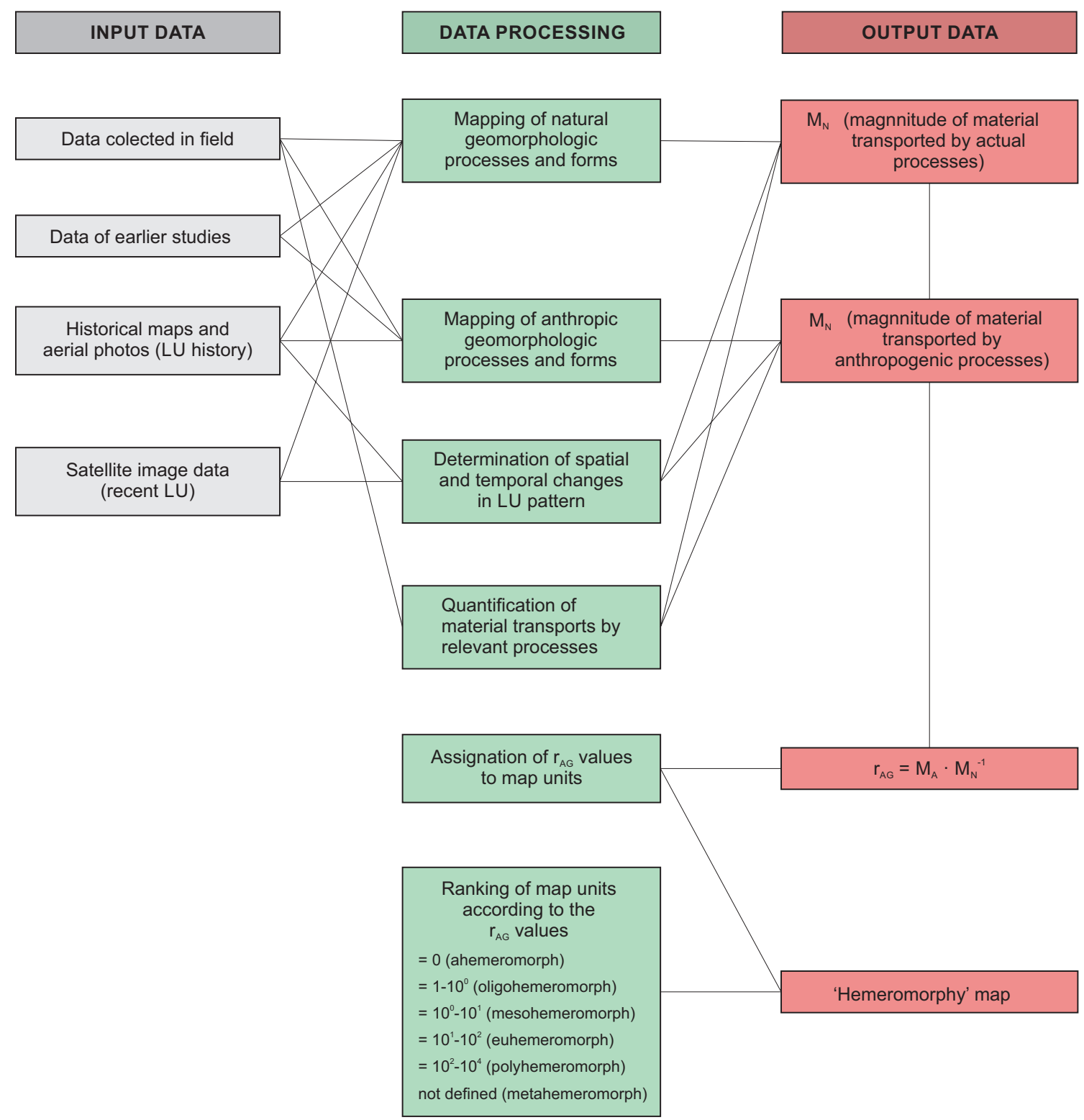

Fig. 1: Flow-chart of data processing and evaluation

measurement in the cases of $M_{a t}, M_{a g}$ and $M_{a q}$, and secondly, we obtained them from the literature (Pinczés and Boros 1967; Pinczés 1971; Kerényi 1994) in the cases of $M_{N}, M_{a e}$ and $M_{a t e}$. When the extent of field measurements $\left(\mathrm{m}^{2}\right.$, ha), the amount of transported material $\left(\mathrm{m}^{3}\right.$ or $\mathrm{t}$ ), and the duration of the process were available from publications, data could be transformed directly into $\mathrm{t} \cdot \mathrm{ha}^{-1} \cdot \mathrm{yr}^{-1}$ values. In other cases $\left(M_{a t}, M_{a g}, M_{a q}\right)$, it was not the process rate, but the volume and mass forms (positive or negative ones) resulting from the process which were measured. In these cases, the time-interval in which the given anthropogenic process was effective and resulted in measurable geomorphological features also had to be considered.

\section{Pilot area}

Tokaj Nagy Hill $\left(21.18 \mathrm{~km}^{2} ; 514 \mathrm{~m}\right)$ is a well definable geographical unit, which can be approximately delimited by the 100 meter elevation contour dividing the dominantly erosional areas from the surrounding alluvial plains of the Tisza and 
Bodrog rivers (Fig. 2). In its present form it is an eroded remnant of a Miocene stratovolcano built up of pyroxene dacite lava flows and, subordinately, pyroxene dacite tuff; moreover, small rhyolite and perlite also occur (ZelenKa 2012). Most of the surface of the volcanic rocks is covered by 1-10 meter thick Quaternary loess, redeposited loess and slope sediments (KerÉNyI 1994; SüMEGI and Hertelendi 1998). The few valleys and numerous gullies are incised radially without any permanent surface water flow. The annual mean temperature is $8.5-9^{\circ} \mathrm{C}$ at the top and almost $10{ }^{\circ} \mathrm{C}$ at the base of the hill. Precipitation varies between 550 and $600 \mathrm{~mm}$ with a clear maximum in summer, when heavy rains are also frequent, causing ephemeral runoff water-flows (Pinczés and Boros 1967). The potential natural vegetation of the hill is deciduous forest, dominated by pedunculate oak (Quercus robur), sessile oak (Quercus petrea), and hornbeam (Carpinus betulus). On exposed steep slopes with shallow soils, forest-steppe mosaics are assumed to be native (SENDTKO 1999).

Agricultural activity started on the hill in the Neolithic age, but it became a significant land forming factor in the early medieval period (BALASSA 1991). The major part of the hill has been cultivated since that time while woods have only remained in areas above $400 \mathrm{~m}$. The cultivated slopes were frequently transformed by the construction of terraces, or landscaped for vine cultivation. Grasslands were traditionally grazed by livestock, and forests and bushes were cut down again and again to obtain more areas for vine cultivation and grazing. A recent development has been the spontaneous reforestation of and shrub development on abandoned vineyards. Some small stone carving pits have been cultivated since the 18th century or earlier, and the first quarries with significant material extraction were opened at the beginning of the 20th century.

There are two settlements in the area, namely Tokaj and Tarcal, with populations of 4200 and 2800 , respectively. Both settlements were founded as early as the 10 th-11th century.

\section{Results and discussion}

\subsection{Natural processes $\left(M_{n e}, M_{n g}\right.$ and $\left.M_{n d}\right)$}

Natural or quasi-natural processes include material loss and supply by gravity driven movements (soil creep), sheet erosion, and wind erosion processes. However, the distinction between natural and anthropogenic accelerated processes is always problematic. That is why the processes were taken into consideration only in those areas where the surface is covered by undisturbed forest, forest steppe or grass vegetation. Since most of the area is affected by anthropogenic geomorphic processes, only estimated data on natural geomorphic processes could be taken into account (see also Fig. 3).

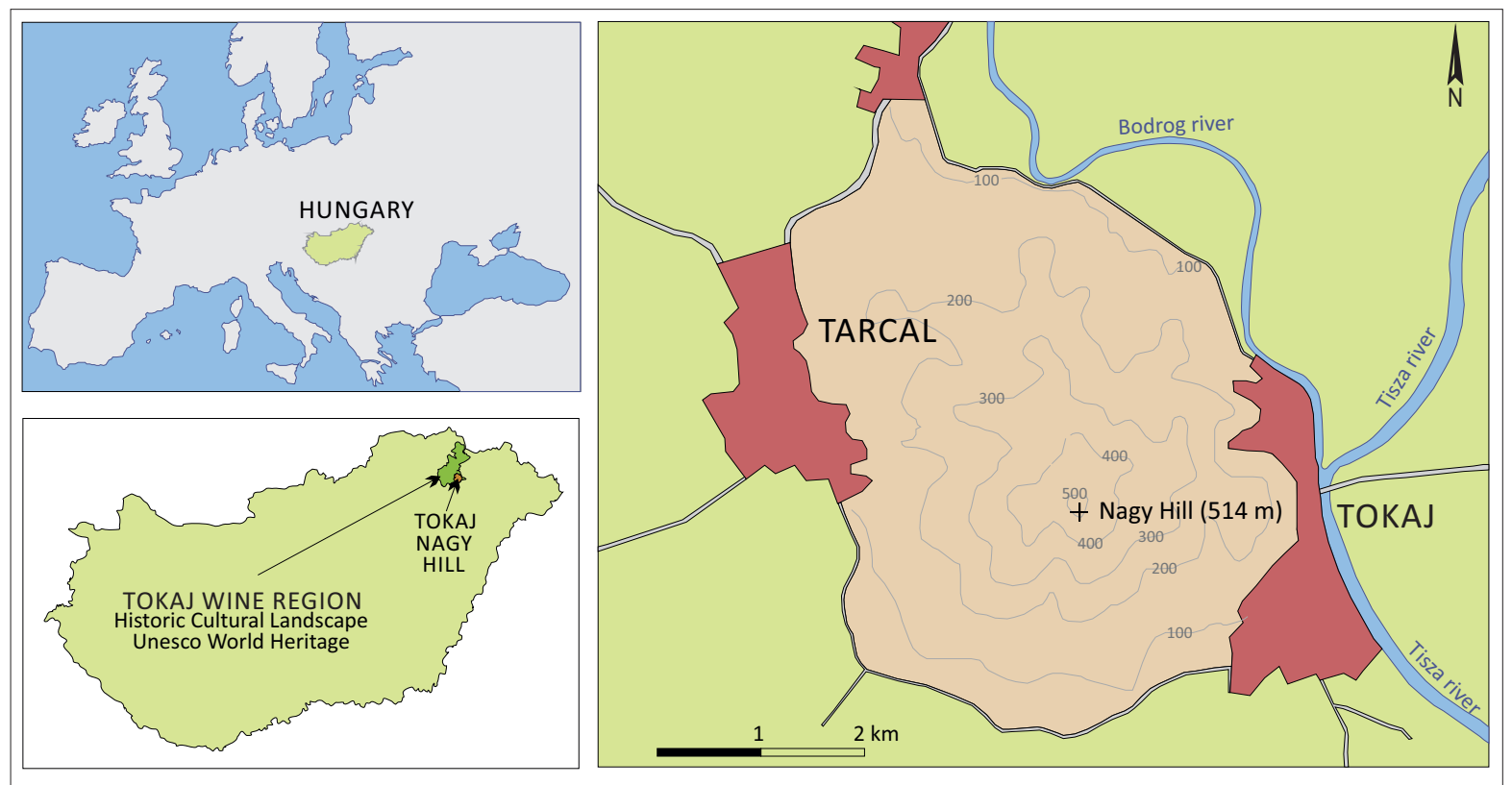

Fig. 2: The pilot area 


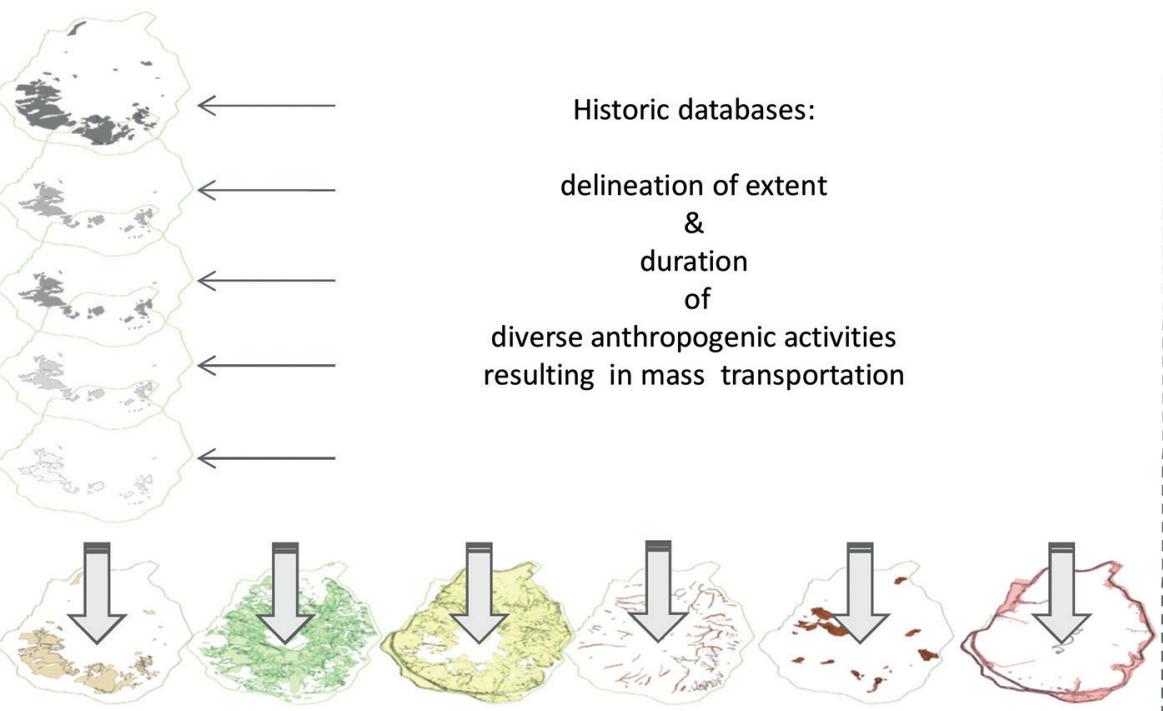

Calculation of mass translocation by anthropogenic processes

Sum of the mass translocation for each polygon
Mapping

natural

processes

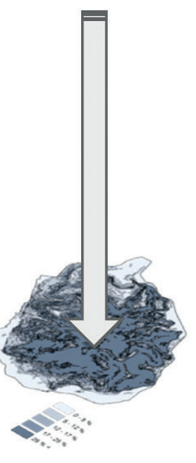

Calculation of mass translocation by natural processes

$\Sigma M_{\mathrm{at}}+\mathrm{M}_{\mathrm{ae}}+\mathrm{M}_{\mathrm{ate}}+\mathrm{M}_{\mathrm{ag}}+\mathrm{M}_{\mathrm{aq}}+M_{\mathrm{ab}}$

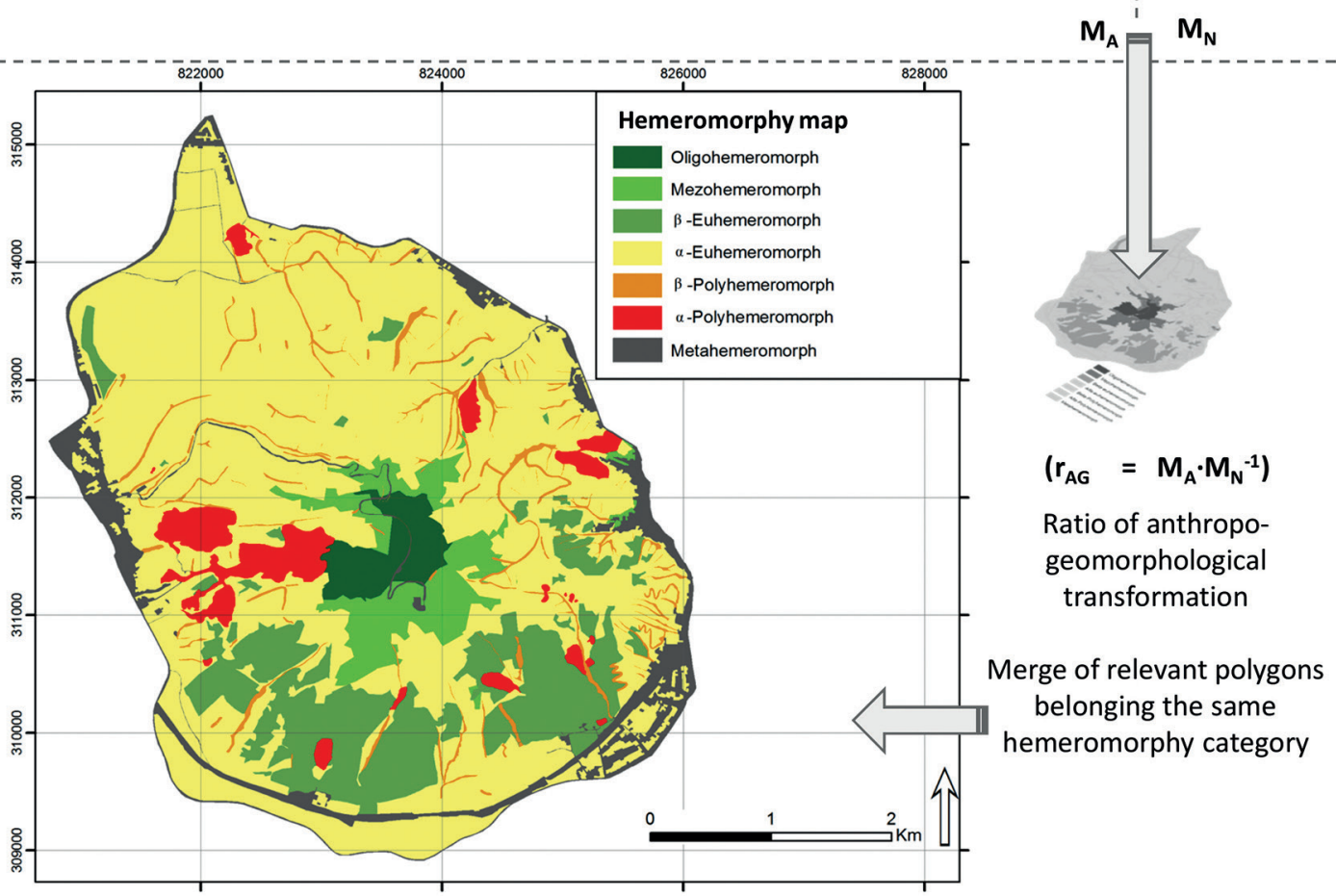

Fig. 3: The process of compiling the hemeromorphy map for the pilot area 
As tectonic uplift leads to a higher rate of erosion, it might be considered a factor of natural processes. The impact of tectonics, however, can be neglected because Nagy Hill is situated precisely at the transitional area between the subsiding Great Hungarian Plain and the uplifting Hungarian Mountain Range; therefore, Quaternary uplift or subsidence cannot be recognized (RÓNAI 1974; RUSZKICZAY-RÜDIGER et al. 2005).

Under natural conditions sediment transport in the pilot area occurs as sheet erosion and wind erosion, and sediment accumulation by surface water flow and deposition of dust. CERDAN et al. (2010) and Verheijen et al. (2009) show that these processes occure at a very low rate in areas of similar climate and morphology if vegetation cover is continuous and constant. Since wind erosion basically depends on the type of vegetation, it can be considered to be negligible for forested hilly areas (PÁszTor et al. 2016); moreover, dust accumulation in the Carpathian Basin is estimated to be as low as $0.032-0.054 \mathrm{t} \cdot \mathrm{ha}^{-1} \cdot$ year $^{-1}$ (VARGA et al. 2016), therefore sediment transport due to aeolian processes can be considered to be negligible for the pilot area $\left(M_{n d} \approx 0\right)$. The intensity of water erosion varies by type of vegetation and by slope steepness as well. CERDAN et al (2010) give the mean rate of water erosion for different quasi-natural vegetation types in Europe as follows: $0.14-0.2 \mathrm{t} \cdot \mathrm{ha}^{-1} \cdot$ year $^{-1}$ in forests, $0.2-0.5 \mathrm{t} \cdot \mathrm{ha}^{-1} \cdot$ year $^{-1}$ in shrublands and $0.3-0.4 \mathrm{t} \cdot \mathrm{ha}^{-1} \cdot$ year $^{-1}$ in grasslands. For estimating erosion rates, data from former field measurements in the area of Nagy Hill and in other areas with com- parable climate, geology and topography were used. Erosion rates were sorted by slope steepness and land use as the two most important factors which controlled them. The combined size of those areas in the pilot area which could be considered as being only affected by natural, is $54.5 \mathrm{ha}(2.6 \%)$ (Tab. 1).

The development of gullies is controlled by slope gradient, soil type and vegetation cover (KERTÉsz 1984; KERTÉsz et al. 1995); however, their formation is associated with accelerated erosion generally induced by land use changes, especially deforestation (MORGAN 1995; ZÁмBó 1971). The results of a detailed study performed in the catchment area of Rakaca Creek (about $50 \mathrm{~km} \mathrm{NW}$ of Nagy Hill) suggest that under natural conditions there are no gullies or, at most, they are in quite a poorly developed state (GÁBRIS et al. 2003). Consequently, natural gully erosion can be regarded as negligible $\left(M_{n g}=0\right)$.

\subsection{Anthropogenic processes}

\subsubsection{Accelerated erosion due to grazing, tram- pling, fire-disturbances and clear cuts in woods or shrubs $\left(=M_{a e}\right)$}

Forests and shrubs with regular cutting and grasslands with grazing belong to this type. These human activities have caused episodically strong sheet or rill erosion (TORRESANI et al. 2019), but they have been followed by longer regeneration periods without any

Tab. 1: Mass translocation rates and spatial extension of dominant geomorphological processes on Tokaj Nagy-Hill

\begin{tabular}{ccc}
\hline Geomorphological processes & $\begin{array}{c}\text { Magnitude of mass } \\
\text { translocation rate } \\
\left(\mathbf{t} \cdot \mathbf{h} \mathbf{~}^{-1} \cdot \mathbf{y r} \mathbf{r}^{-1}\right)\end{array}$ & $\begin{array}{c}\text { Area dominated by the } \\
\text { process in the pilot area } \\
\mathbf{( \% )}\end{array}$ \\
\hline$M_{N}$ (natural) & $<10^{0}$ & 2.6 \\
$M_{n e}$ (natural sheet erosion)* & $10^{-1}-10^{0}$ & 2.6 \\
$M_{A}$ (anthropogenic) & & 89.7 \\
$M_{a e}$ (accelerated sheet erosion)* & $10^{-1}-10^{0}$ & 5.1 \\
$M_{a t e}$ (tillage erosion)**** & $5.6-46.3$ & 62.4 \\
$M_{a t}$ (terracing)***** & 18.0 & 14.5 \\
$M_{a g}$ (accelerated gully erosion)*** & 84.8 & 2.8 \\
$M_{a q}$ (excavation)** & 5727.3 & 4.9
\end{tabular}

\footnotetext{
Human geo-environment

(processes blocked, or compensated)

n.d.

*Cerdan et al. 2010.

**Calculated based on LiDAR, map data (extent) and field measurements (height of walls)

***Calculated based on field measures (depth, width) and maps (total length).

****PINCZÉs 1967; PinCZÉs and Boros 1971; KeRÉNYI 1994.

*****Calculated based on maps (identified extent of terraces) and field surveys (width and height of terraces)
}

7.7 
significant anthropogenic influence. Areas which had never been cultivated but whose natural vegetation cover was disturbed or completely removed in certain periods were classified into this category. Mass translocation rates for processes of this type were not measured directly in the field for Tokaj Nagy Hill, but there is data in the literature related to areas with similar geographical conditions (PINCZÉs and BOROs 1967; PINCZÉs 1971). According to our estimation, accelerated erosion due to any kind of vegetation disturbance is a dominant anthropogenic geomorphological process affecting $111.2 \mathrm{ha} \mathrm{(5.1 \% )}$ (Tab. 1).

\subsubsection{Tillage erosion $\left(=M_{a t}\right)$}

This category involves areas influenced by agricultural cultivation for longer periods (in some places more than 300 years), even if they were uncultivated for shorter or longer periods. Therefore, different time spans were considered for the individual spatial units. Due to the high erodibility of the loess cover, strong sheet and rill erosion (tillage erosion) were always significant problems in the history of vine cultivation on Nagy Hill. Therefore, there are numerous references in the literature for estimating the magnitude of the process. The various cultivation techniques blurred the straight forward dependence of erosion rates on slope, according to the field experiments on Tokaj Nagy Hill (KERÉNYI 1994).

Tillage erosion is the dominant and the most typical anthropogenic process on 1321.8 ha (62.4\%) of the area (Tab. 1). Based on numerous field measurements made by PinCZÉs and Boros (1967) and KERÉNYI (1994), the mean erosion rate could be calculated for slopes used for viniculture. Surprisingly, the data show no correlation between erosion rate and slope. Besides inclination, the cultivation method (head-trained or cordon trained), the distance of vine-stocks and vine rows, and the age of the plantation all significantly affect erosion rates. Moreover, the field studies were carried out during periods with different meteorological conditions. In particular the amount and intensity of precipitation might have differed considerably.

\subsubsection{Terrace construction or leveling, landscap- ing for vine-cultivation $\left(=M_{a t}\right)$}

These areas could be characterized by a high volume of material movement during their building period, but after that erosion processes are inhibit- ed for a longer time (BALASSA 1991; TAROlli et al. 2014). The first written documentation dates back to the early 17 th century; however, after the decline of viticulture caused by the phylloxera disaster in 1886, stone-walled terraces were no longer built in Tokaj. Even so, existing terraces were maintained and cultivated until the middle of the 20th century. Therefore, the duration of this anthropogenic process lasted for ca. 300 years. Mapping areas in this category was possible with the use of aerial photographs from different time-sections, whereas maps do not depict these constructions. Since abandoned terraces are mostly overgrown by dense vegetation, remotely sensed data from the early succession phases, or images from seasons without foliage, were analysed. The spatial density $\left(\mathrm{m} \cdot \mathrm{ha}^{-1}\right)$, height $(\mathrm{m})$ and width $(\mathrm{m})$ of retaining walls and width of terraces $(\mathrm{m})$ were measured in the field. Approximately one fifth $(15.5 \mathrm{~km})$ of all terrace walls identifiable on aerial photographs (total length: $81.6 \mathrm{~km}$ ) were surveyed in the field for measuring. The most recent vineyard plantations (in the last 60 years) were established without the construction of stone walls, but they required earth construction works of similar volume. The volume of material moved by the terracing processes was calculated based on the averaged shape and extension of terraces. In the case of older terraces, the amount of the stone material was also added, where the mean density of dry stone walls was regarded as $2 \mathrm{t} \cdot \mathrm{m}^{-3}$. The density of filling material of terraces was regarded as $1.3 \mathrm{t} \cdot \mathrm{m}^{-3}$ based on field measurements.

In the case of landscaped and terraced slopes, besides the above mentioned processes, terrace construction, leveling, and other significant earth construction works dominate surface development. The extent of the terraced slopes with dry constructed retaining walls occurring on the southern side of the hill is 129 ha $(6.1 \%)$. The mean distance of retaining walls is 7.4 meters, and their mean spatial density is $632 \mathrm{~m} \cdot \mathrm{ha}^{-1}$. Based on 304 cases measured in the field, the mean height and mean width are 1.30 and $0.93 \mathrm{~m}$, respectively. Using these data, the mass moved by terrace construction was estimated to be $6.19 \mathrm{t} \cdot \mathrm{ha}^{-1} \cdot$ year $^{-1}$. To level the slope between the retaining walls, a significant mass of material has to be moved, too. Calculating with the above mentioned data and with a constant density of the soil material $\left(1.3 \mathrm{t} \cdot \mathrm{m}^{-3}\right)$, the corresponding rate is 14.95 $\mathrm{t} \cdot \mathrm{ha}^{-1} \cdot \mathrm{year}^{-1}$. Hence, the rate of mass moved by the construction of stone-walled vineyard terraces was estimated to be $21.14 \mathrm{t} \cdot \mathrm{ha}^{-1} \cdot$ year $^{-1}$ including the slope-leveling and wall construction. A further 177.5 
Tab. 2: Spatial extent and $r_{A G}$ values of hemeromorphotops within the pilot area

\begin{tabular}{lrrc}
\hline Hemeromorphy & \multicolumn{2}{c}{ Area } & $\boldsymbol{r}_{A G}$ \\
& $(\mathrm{ha})$ & $(\%)$ & \\
\hline Ahemeromorph & 0 & 0 & 0 \\
Oligohemeromoph & 54.5 & 2.6 & $<1$ \\
Mesohemeromorph & 111.2 & 5.2 & $1-10$ \\
Euhemeromorph & & & \\
$\quad$ b-euhemeromorph & 306.5 & 14.5 & 36 \\
$\quad 1321.8$ & 62.4 & $11.2-92.6$ \\
$\quad$ a-euhemeromorph & & & 169.6 \\
Polyhemeromorph & 58.7 & 2.8 & 11454.6 \\
$\quad$ b-polyhemeromorph & 103.9 & 4.9 & n.d. \\
$\quad$ a-polyhemeromorph & 162.1 & 7.7 & \\
Metahemeromorph & &
\end{tabular}

ha $(8.4 \%)$ of leveled vineyards without retaining walls were mapped. The size of these earth-terraces is similar to that of the older ones with stone walls, and the relevant material-deposition rate is estimated to be $14.95 \mathrm{t} \cdot \mathrm{ha}^{-1} \cdot$ year $^{-1}$. In total, $18.04 \mathrm{t} \cdot \mathrm{ha}^{-1} \cdot$ year $^{-1}$ were taken into account as the mean material transportation rate for the two different types of terraced slopes (Tab. 1).

\subsubsection{Erosion gullies $\left(=M_{a g}\right)$}

Gullies develop under the influence of long-time slope cultivation in downslope positions where surface runoff concentrates (POESEN et al. 2003). The areas of this type were mapped on 1:10 000 topographic maps (1989) and remote sensing data (aerial photographs from 1957 and 1981). To measure the depth $(\mathrm{m})$, width $(\mathrm{m})$ and volume of the eroded material, LiDAR data (2014) with 1x1 m resolution was used, and averaged data for volume calculations were applied. The density of the materials - dominantly loess $\left(1.3 \mathrm{t} \cdot \mathrm{m}^{-3}\right)$ - was taken as constant. However, estimating the duration of the gully development is very problematic, since it is not always obvious whether they are the results of natural processes or human activities. Maybe some gullies had existed on the hill before anthropogenic influence became stronger. Forest clearing and expansion of land cultivation, however, increased the amount of runoff reactivating gentle slopes of mature gullies in the "golden age" of the viticulture of the Tokaj Nagy Hill starting in the 16th century (BALASSA 1991). As a general approximation, we assumed a 500 year period for the development of the recent gullies. Surfaces dominat- ed by anthropogenic generated or reactivated gully development mass have a translocation of rate 84.8 $\mathrm{t} \cdot \mathrm{ha}^{-1} \cdot$ year $^{-1}$ and cover 58.7 ha $(2.8 \%$ ) (Tab. 1).

\subsubsection{Quarrying $\left(=M_{a q}\right)$}

Quarries and their spoil heaps represent areas with a very high rate of material transport at the time of their production, and with significant, but random mass transport after their abandonment or recultivation. Material removal rates in the case of quarries were calculated on the basis of the volumetric amount of excavated material. The area of each quarry was calculated based on topographic maps (1989) and aerial photographs (1981), while the shape and height of excavation walls as well as the excavated volume was measured by LiDAR data (2014) and field measurements. The density of the excavated pyroxene dacite material $\left(2.65 \mathrm{t} \cdot \mathrm{m}^{-3}\right)$ and the time of excavation (100 years) was taken as a constant. The volume of the excavated material was calculated and converted to $\mathrm{t} \cdot \mathrm{ha}^{-1} \cdot \mathrm{yr}^{-1}$ values for all quarries. The total area affected by quarries extends over 103.9 ha $(4.9 \%)$. The sum of material excavated is more than 44.3 million tons, the mean mass translocation intensity rate of the process amounts to 5727.3 $\mathrm{t} \cdot \mathrm{ha}^{-1} \cdot \operatorname{year}^{-1}$ (Tab. 1).

\subsubsection{Roads, railways and built-up areas $\left(=M_{a b}\right)$}

Built-up areas such as settlements, constructed roads, industrial sites, and all sealed surfaces, where the surface is not only completely transformed by 
anthropogenic processes but also permanently controlled by continuous human activity, were classified in a separate category. Their extent was mapped using topographic maps and remotely sensed data. No rate for material deposition and material dislocation was assigned to this category, since any geomorphological processes are inhibited on these surfaces. These areas make up $7.7 \%$ of the total area (162.1 ha). In the case of this human-geoenvironment, no rates were calculated (Tab. 1).

The extent of hemeromorphy categories within the pilot area is presented in figure 3 , and values are listed in table 2.

\section{Conclusions}

The first attempt to figure the spatial distribution of the Earth's surface modifying activity of humans was made by Hooke (1999). On his 3D grid map of the United States peaks are proportional to the estimated amount of man-moved mass. For comparison, he also published a separate 3D grid map concerning the mass moved by fluvial erosion; however, this 3D grid pair is rather an illustration than demonstration of the spatial distribution of the grade of the anthropic effect on geomorphological processes. Map of direct human impact on the topography of Hungary represents areas of anthropogenic landforms of water management, housing development, industry, transportation, agriculture, etc. as well as major anthropogenic linear landforms (Lóczy and PIRKHOFfer 2009). The map is based on land use pattern and refers only to the types of human action without any quantitative concerns; therefore, it can be regarded as a mapped inventory of principal human induced surface transformation and landforms. Recently, based on the empirical relationship between the degree of landscape organization and the amount of human-made alteration, TAROLLI et al. (2017) made attempts at detecting anthropogenic topographic signature. By using satellite data, they expressed the degree of anthropogenic modification of morphology on a dimensionless percentile scale; however, their approach does not quantify the degree of geomorphological activities of humans.

Aim of our studies was to develop a simple index for expressing and mapping the degree of anthropic geomorphological transformation of the Earth's surface. For the determination of human geomorphological impact on the surface the ratio of man-moved mass $\left(M_{A}\right)$ and that of natural geomorphological processes $\left(M_{N}\right)$ was estimated yielding dimensionless values of $r_{A G}\left(M_{A} \cdot M_{N}^{-1}\right)$. This index is independent of the magnitude, quality and intensity of natural and anthropogenic surface-shaping processes; therefore, it can be used to quantitatively compare the human geomorphological impact on landscapes that are far apart and exhibit completely different conditions.

As there is no upper limit of the values of $r_{A G}$, the so-called hemeromorphotop categories should be introduced and can be used as units for mapping anthropic geomorphological impact both on smaller and larger scales. Moreover, using historical data temporal changes in anthropic geomorphological activity could be also traced. Similarly, the quantification of the re-naturalization process would also be possible by comparing data of a longer time span.

It should be noted, however, that our results refer to a relatively small pilot area; therefore, depending on further experience, some details of our approach may require some modifications. Moreover, making a database concerning the degree of natural processes and human-made surface transition requires time-consuming fieldwork. At the same time, we think that an integration of the hemeromorphy concept and the satellite data based anthropogenic topographic signature technique (TAROLLI 2017) could facilitate quantifying and mapping the degree of anthropogenic surface transformation on a larger scale.

\section{Acknowledgements}

The research was financed by the Higher Education Institutional Excellence Programme (NKFIH-1150-6/2019) of the Ministry of Innovation and Technology in Hungary, within the framework of the $4^{\text {th }}$ thematic programme of the University of Debrecen. The research work of Tibor József Novák was supported by the János Bolyai Research Scholarship of the Hungarian Academy of Sciences (BO/00448/17/10) and by the ÚNKP-19-4-DE-129 new national excellence program of the Ministry for Innovation and Technology.

\section{References}

BAlassa, I. (1991): Tokaj-Hegyalja szőlője és bora [Vineyards and wine of Tokaj-Hegyalja]. Tokaj-Hegyaljai ÁG: Borkombinát. Tokaj (in Hungarian).

Borgatti, L. and Soldati, M. (2005): Geomorphological hazard and human impact in mountain environment. In: Geomorphology 66, 7-11. https://doi.org/10.1016/j. geomorph.2004.10.001 
Brown, A. G.; Tooth, S.; Bullard, J. E.; Thomas, D. S. G.; Chiverell, R. C.; Plater, A. J.; Murton, J.; Thorndycraft, V. R.; Tarolli, P.; Rose, J.; Wainwright, J.; Downs, P. and Aalto, R. (2017): The geomorphology of the Anthropocene: emergence, status and implications. In: Earth Surface Processes and Landforms 42, 71-90. https://doi.org/10.1002/esp.3943

BüdEL, J. (1978): Klimageomorphologie. Berlin-Stuttgart.

Byizigiro, R. V., RaAB, T. and Maurer, T. (2015): Small-scale opencast mining: an important research field for anthropogenic geomorphology. In: Die Erde 146 (4), 213-231.

Cendero, A.; Marchetti, M.; Panizza, M. and Rivas, V. (2001): Geomorphology and Environmental Impact Assessment. In: MARCHETTI, M. and Rivas, V. (eds.) (2001): Geomorphology and environmental impact assessment. Lisse, 1-5.

Cerdan, O.; Govers, G.; Le Bissonnais, Y.; Van Oost, K.; Poesen, J.; Saby, N.; Gobin, A.; Vacca, A.; Quinton, J.; Auerswald, K.; KitK, A.; Kwaad, F. J. P. M.; Raclot, D.; Ionita, I.; Rejman, J.; Rousseva, S. T.; Muxart, T.; Roxo, M. J. and Dostal, T. (2010): Rates and spatial variations of soil erosion in Europe: A study based on erosion plot data. In: Geomorphology 122, 167-177. https://doi.org/10.1016/j. geomorph.2010.06.011

Chartin, C.; Evrard, O.; Salvador-Blanes, S.; Hinschberger, F; Van Oost, K.; Lefèvre, I.; Daroussin, J. and Macaire, J-J. (2013): Quantifying and modelling the impact of land consolidation and field borders on soil redistribution in agricultural landscapes (1954-2009). In: Catena 110, 184-195. https://doi.org/10.1016/j.catena.2013.06.006

Dulias, R. (2016): The impact of mining on the landscape. A study of the Upper Silesian coal basin in Poland. Cham. https://doi.org/10.1007/978-3-319-29541-1

Eldis, E. C. and Ramankutty, N. (2008): Putting people in the map: anthropogenic biomes of the world. In: Frontiers in Ecology and the Environment 6, 439-447. https://doi. org/10.1890/070062

Ferrer-Valero, N.; Hernández-Calvento, L. and HernánDEZ-Cordero, A. I. (2017): Human impacts quantification on the coastal landforms of Gran Canaria Island (Canary Islands). In: Geomorphology 286, 58-67. https://doi. org/10.1016/j.geomorph.2017.02.028

Ford, J. R.; Kessler, H.; CoOper, A. H.; Price, S. J. and Humpage, A. J. (2010): An enhanced classification for artificial ground. British Geological Survey Internal Report(IR/04/038). Nottingham. http://nora.nerc.ac.uk/id/eprint/10931/

GÁBris, G.; KerTÉsZ, Á. and ZÁmBÓ, L. (2003): Land use change and gully formation over the last 200 years in a hilly catchment. In: Catena 50, 151-164. https://doi.org/10.1016/ S0341-8162(02)00141-8

Gares, P. A.; Sherman, D. J. and Nordstrom, K. F. (1994): Geomorphology and natural hazards. In: Geomorphology 10, 1-18. https://doi.org/10.1016/B978-0-444-820129.50005-0
Giardino, J. R.; and Marston, R. A. (1999): Engineering geomorphology: an overview of changing the face of earth. In: Geomorphology 31 (1), 1-11. https://doi. org/10.1016/S0169-555X(99)00069-0

Goudie, A. (1993): Human influence in geomorphology. In: Geomorphology 7 (1-3), 37-59. https://doi. org/10.1016/0169-555X(93)90011-P

Goudie, A. and Viles, H. A. (2016): Geomorphology in the Anthropocene. Cambridge. https://doi.org/10.1017/ CBO9781316498910

HAfF, P. K. (2003): Neogeomorphology, prediction, and the anthropic landscapes. In: Wilcock, P. R. and Iverson, R. M. (eds)(2003): Prediction in geomorphology. Washington, 15-26. https://doi.org/10.1029/135GM02

Harnischmacher, S. and Zepp, H. (2014): Mining and its impact on the earth surface in the Ruhr District (Germany). In: Zeitschrift für Geomorphologie, Supplementary Issues 58 (3), 3-22. https://doi.org/10.1127/0372-8854/2013/S-00131

Hooke, R. L. (1994): On the efficacy of humans as geomorphic agents. In: GSA Today. 4 (9), 217, 224-225. https://www.geosociety.org/gsatoday/archive/4/9/ pdf/i1052-5173-4-9-sci.pdf

- (1999): Spatial distribution of human geomorphic activity in the United States: comparison with rivers. In: Earth Surface Processes and Landforms 24, 687-692. https://doi. org/10.1002/(SICI)1096-9837(199908)24:8\%3C687::AI D-ESP991\%3E3.0.CO;2-\#

- (2000): On the history of humans as geomorphic agents. In: Geology 28(9), 843-846. https://doi.org/10.1130/00917613(2000)28\%3C843:OTHOHA\%3E2.0.CO;2

Houben, P.; Hoffmann, T.; Zimmermann, A. and Dikau, R. (2006): Land use and climatic impacts on the Rhine system (RheinLUCIFS): quantifying sediment fluxes and human impact with available data. In: Catena 66, 42-52. https://doi.org/10.1016/j.catena.2005.07.009

JaLAs, J. (1955): Hemerobe und hemerochore Pflanzenarten. Ein terminologischer Reformversuch. In: Acta Societatia Pro Fauna et Flora Fennica 72, 1-15.

Kareiva, P.; Watts, S.; McDonald, R. and Boucher, T. (2007): Domesticated nature: shaping landscapes and ecosystems for human welfare. In: Science 316, 1866-1869. https://doi.org/10.1126/science.1140170

Kerény, A. (1994): Loess erosion on the Tokaj Big-Hill. In: Quaternary International 24, 47-52 https://doi. org/10.1016/1040-6182(94)90038-8

Kertész, Á. (1984): The role deep-cut tracks in linear erosion. In: ENyedi, G. and Pecsi, M. (eds.): Geographical essays in Hungary. Budapest, 47-56.

Kertész, Á.; Huszźr, T. and Lóczy, D. (1995): Land use changes in Lake Balaton catchment. In: Simmons, I. G. and Mannion, A. M. (eds): The changing nature of the people - environment relationship: evidence from a variety of archives. Prague, 69-78. 
Lausch, A. and Herzog, F. (2002): Applicability of landscape metrics for the monitoring of landscape change: issues of scale, resolution and interpretability. In: Ecological Indicators 2, 3-15. https://doi.org/10.1016/ S1470-160X(02)00053-5

Lóczy, D. Pirkhoffer, E. (2009): Mapping direct human impact on the topography of Hungary. In: Zeitschrift für Geomorphologie, Supplementary Issues 53 (2), 215-222. https://doi.org/10.1127/03728854/2009/0053S3-0215

LOH, J and WaCKERNAGEL, M, (eds.) (2004): Living planet report 2004. World wilde fund for nature. http:// awsassets.panda.org/downloads/lpr_living_planet_report_2004.pdf

Martinez-Casasnovas, J. A. (2003): A spatial information technology approach for the mapping and quantification of gully erosion. In: Catena 50, 293-308. https:// doi.org/10.1016/S0341-8162(02)00134-0

Morgan, R. P. C. (1995): Soil erosion and conservation. Harlow, UK.

NIR, D. (1983): Man, a geomorphological agent. An introduction to anthropic geomorphology. Dordrecht-Boston-London.

PÁsztor, L.; Négyesi, G.; Laborczi, A.; Kovács, T.; LÁszló, E. and BiHARI, Z. (2016): Integrated spatial assessment of wind erosion risk in Hungary. In: Natural Hazards and Earth System Sciences 16, 2421-2432. https://doi. org/10.5194/nhess-16-2421-2016

Phillips, J. D. (2009): Landscape evolution space and the relative importance of geomorphic processes and controls. In: Geomorphology 109 (3-4), 79-85. https:/ / doi. org/10.1016/j.geomorph.2009.01.007

PInCZÉs, Z. (1971): Die Formen der Bodenerosion und der Kampf gegen sie in Weingebiet des Tokajer Berges. Debrecen.

Pinczés, Z. and Boros, L. (1967): Schneeschmelzerosion in den Tokajer Weingärten. In: Acta Geographica Debrecina 12-13 (5-6), 101-113.

Poesen, J.; Nachtergaele, .J; Verstraeten, G. and ValenTIN, C. (2003): Gully erosion and environmental change: importance and research needs. In: Catena 50, 91-133. https://doi.org/10.1016/S0341-8162(02)00143-1

Price, S. J.; Ford, J. R.; Cooper, A. H. and Neal, C. (2011): Humans as major geological and geomorphological agents in the Anthropocene: the significance of artificial ground in Great Britain. In: Philosophical Transactions of the Royal Society A 369, 1056-1084. https://doi. org/10.1098/rsta.2010.0296

Pye, K. and Blott, S. J. (2014): The geomorphology of UK estuaries: the role of geological controls, antecedent conditions and human activities. In: Estuarine, Coastal and Shelf Science 150, 196-214. https://doi. org/10.1016/j.ecss.2014.05.014
RÓNAI, A. (1974): Size of Quaternary movements in Hungary's area. In: Acta Geologica Academiae Scientiarum Hungaricae 18, 39-44.

RózsA, P. (2007): Attempts at qualitative and quantitative assessment of human impact on the landscape. In: Geografia Fisica e Dinamica Quaternaria 30, 233-238.

- (2010): Nature and extent of human geomorphological impact - a review. In: SzABÓ, J.; DÁvID, L. and Lóczy, D. (eds) (2010): Anthropogenic geomorphology. A guide to man-made landforms. Dordrech-Heidelberg-London-New York, 273-291. https:/ / doi.org/10.1007/97890-481-3058-0_17

Ruszkiczay-RÜdiger, Z.; Fodor, L.; BADA, G.; LeÉL-Össy, S.; Horváth, E. and DunaI, T. J. (2005): Quantification of Quaternary movements in the central Pannonian Basin: a review of chronologic data along the Danube River, Hungary. In: Tectonophysics 410, 157-172. https:/ / doi.org/10.1016/j.tecto.2005.05.048

SEndTKo A. (1999): Die Xerothermvegetation brachgefallener Rebflächen im Raum Tokaj (Nordost-Ungarn). Pflanzensoziologische und populationsbiologische Untersuchungen zur Sukzession. In: Phytocoenologia 29, 345-448. https://doi.org/10.1127/phyto/29/1999/345

SHERLOCK, R. L. (1922): Man as a geological agent - an account of his action on inanimate nature. London.

- (1931): Man's influence on the earth. London.

Slabá, E.; Jakubínský, J.; Báčová, R.; Herber, V. and KubíČEK, P. (2015): Inventory of anthropogenic landforms for flood management in small catchments of the Czech Republic. In: Zeitschrift für Geomorphologie, Supplementary Issues 59 (2), 75-93. https://doi. org/10.1127/zfg_suppl/2015/S-59205

Sofia, G.; Marinello, F. and Taroldi, P. (2016): Metrics for quantifying anthropogenic impacts on geomorphology: road networks. In: Earth Surface Processes and Landforms 41 (2), 240-255. https:/ / doi.org/10.1002/esp.3842

Sukopp, H. (1969): Der Einfluss des Menschen auf die Vegetation. In: Vegetatio 17, 360-371. https://doi. org/10.1007/BF01965917

Sümegi, P. and Hertelendi, E. (1998): Reconstruction of microenvironmental changes in the Kopasz Hill loess area at Tokaj (Hungary) between 15 and $70 \mathrm{ka} \mathrm{BP}$. In: Radiocarbon 40 (2), 855-863. https://doi.org/10.1017/ S0033822200018828

Szabó, J.; DÁvid, L. and Lóczy, D. (eds.) (2010): Anthropogenic geomorphology. A guide to man-made landforms. Dordrecht-Heidelberg-London-New York. https://doi. org/10.1007/978-90-481-3058-0

Taroldi, P. (2014): High-resolution topography for understanding earth surface processes: opportunities and challenges. In: Geomorphology 216, 295-312. https:/ / doi.org/10.1016/j.geomorph.2014.03.008 
Tarolli, P.; Preti, F. and Romano, N. (2014). Terraced landscapes: from an old best practice to a potential hazard for soil degradation due to land abandonment. In: Anthropocene 6, 10-25. https://doi.org/10.1016/j.ancene.2014.03.002

Tarolli, P.; Sofia, G. and Ellis, E. (2017): Mapping the topographic fingerprints of humanity across Earth, In: Eos 98. https://doi.org/10.1029/2017EO069637

Torresani, L.; Wu, J.; Masin, R.; Penasa, M. and Tarolli, P. (2019): Estimating soil degradation in montane grasslands of north-eastern Italian Alps (Italy). In: Heliyon 5. https://doi.org/10.1016/j.heliyon.2019.e01825

Vanwalleghem, T.; Gómez, J. A.; Infante Amate, J.; GonZalez de Molina, M.; Vanderlinden, K.; Guzmán, G.; LagunA, A. and Giráldez, J. V. (2017): Impact of historical land use and soil management change on soil erosion and agricultural sustainability during the Anthropocene. In: Anthropocene 17, 13-19. https:/doi. org/10.1016/j.ancene.2017.01.002

Varga, G.; Cserháti, C.; KovÁcs, J. and Szalai, Z. (2016): Saharan dust deposition in the Carpathian Basin and its possible effects on the interglacial soil formation. In: Aeolian Research 22, 1-12. https://doi.org/10.1016/j. aeolia.2016.05.004

Verheijen, F. G. A.; Jones, R. J. A.; Rickson, R. J. and Smith, C. J. (2009): Tolerable versus actual soil erosion rates in Europe. In: Earth Science Reviews 94 (1-4), 23-38. https://doi.org/10.1016/j.earscirev.2009.02.003

Verstraeten, G; Lang, A. and Houben, P. (2009): Human impact on sediment dynamics - quantification and timing. In: Catena 77, 77-80. https://doi.org/10.1016/j. catena.2009.01.005

Zalasiewcz, J.; Williams, M.; Haywood, A. and Ellis, M. (2011): The Anthropocene: a new epoch of geological time? In: Philosophical Transaction of the Royal Society A, 369, 835-841. https://doi.org/10.1098/ rsta.2010.0339

ZÁmBÓ, L. (1971): Study of preformed loess gullies. In: Acta Geographica Debrecina 10, 113-116.

Zelenka, T.; Gyarmati, P. and Kiss, J. (2012): Paleovolcanic reconstruction in the Tokaj Mountains. In: Central European Geology 55 (1), 49-84. https://doi.org/10.1556/ CEuGeol.55.2012.1.4

\section{Map data}

Arcanum Kft (2004): georeferred digital edition of the 1st Military Survey of the Habsburg Empire, map sheets: col XXIII. section 13 \& col XXIII. section 14 (1782-85). DVD, Budapest, ISBN: 9639374954

Arcanum Kft (2005): georeferred digital edition of the 2nd Military Survey of the Habsburg Empire, map sheets: col XLI., section 44 \& col XLII section 44. (1858) DVD, Budapest, ISBN: 9639374954
Arcanum Kft (2007): geo-referred digital edition of the 3rd Military Survey of the Habsburg Empire, map sheets 4766 \&4767 (1883-84), 1:25.000, DVD, Budapest, ISBN: $978-963-7374-54-8$

Topography maps from the time of the WW II. (1940's), HM- Hadtörténeti Intézet és Múzeum Térképtár, map sheets: 4766/K, 4767/NY, original scale: 1:50000 in: Tímár G., Molnár G., Székely B., Biszak S., Jankó A.: Topography maps of Hungary from the time of the WW II.. Arcanum Adatbázis Kft., HM-HIM, HM-GEOSZ, Budapest, ISBN 978-963-7374-71-5 (in Hungarian)

1:25000 scale topography maps ("New Survey") (1953-1959), HM Térképészeti Intézet, Budapest, (in Hungarian)

Topographic Maps of Hungary 1:10 000 in EOTR projection, map sheets: 89-113; 89-114; 89-131; 89-132 (198589), Kartográfiai Vállalat, Budapest(in Hungarian)

Google Earth 2011, http://www.google.com/intl/hu/ earth/index.html

Aerial photographs of Tokaj Nagy-Hill, 1981, Archive of the Geography Institute, Debrecen

Aerial photographs of Tokaj Nagy-Hill, 1957,

Digital orthophotographs, Tokaj, Nagy-Hill, 2000 CFöldmérési és Távérzékelési Intézet, Budapest

Authors

Dr. Péter Rózsa

University of Debrecen

Faculty of Sciences and Technology Department of Mineralogy and Geology

Egyetem tér 1. 4032 Debrecen Hungary rozsa.peter@science.unideb.hu

Dr. József Incze Szabolcs Balogh

Dr. Tibor József Novák University of Debrecen Faculty of Sciences and Technology Department of Landscape Protection and Environmental Geography

Egyetem tér 1. pf: 400 4002 Debrecen

Hungary injocooo@hotmail.com balogh.szabolcs@science.unideb.hu novak.tibor@science.unideb.hu 